\title{
Estimasi Besarnya Biaya Proyek Akibat terjadinya Rework pada Pekerjaan Finishing
}

\author{
Ni Kadek Sri Ebtha YUNI ${ }^{1 *}$ \\ ${ }^{1}$ Jurusan Teknik Sipil, Politeknik Negeri Bali, email : ebthayuni@pnb.ac.id
}

\author{
Sejarah artikel \\ Diserahkan: \\ Dalam bentuk revisi: 5 Mei 2021
}

\author{
Diterima: $\quad 12$ Mei 2021 \\ Tersedia online: $\quad 31$ Mei 2021
}

\begin{abstract}
One of the problems that is often experienced at the project implementation stage is a rework. This study analyzes architectural work or work at the finishing stage. The data were obtained through structured interviews with selected respondents, namely from the contractor and construction management consultants to obtain work items that had reworked and their causes. Another required data is shopdrawing images. Furthermore, the work volume calculation is carried out. Based on the results of the interview, it was found that 20 work items had reworked, namely 13 jobs caused by a lack of communication between contractors, 5 jobs due to a design change from the planner, and 2 jobs caused by an error in the contractor's work method. Based on these items and the shopdrawing picture, it is continued by describing the work that has been reworked in more detail, then calculating the volume. To analyze the unit price, the contract price has been agreed between the contractor and the owner. The results of the cost estimation carried out were the causes of successive rework were a lack of communication of Rp 140,654, 089 or 54.4\%, a design change of Rp 111,540,625 or 43.1\%, and errors in working methods of $R p$ 6,454,495 or $2.5 \%$.
\end{abstract}

Keywords: architectural work, cost estimation, rework

\begin{abstract}
Abstrak
Salah satu permasalahan yang sering dialami pada tahap pelaksanaan proyek adalah adanya pekerjaan ulang atau rework. Penelitian ini menganalisis pekerjaan arsitektur atau pekerjaan pada tahap finishing. Data-data diperoleh melalui wawancara terstruktur dengan responden yang terpilih yaitu dari pihak kontraktor dan konsultan manajemen konstruksi untuk memperoleh item-item pekerjaan yang mengalami rework dan penyebabnya. Data lain yang diperlukan adalah gambar shopdrawing. Selanjutnya dilakukan perhitungan volume pekerjaan. Berdasarkan hasil wawancara diperoleh 20 item pekerjaan yang mengalami rework, yaitu 13 pekerjaan disebabkan oleh kurangnya komunikasi antar kontraktor, 5 pekerjaan disebabkan adanya perubahan desain dari perencana, dan 2 pekerjaan disebabkan oleh kesalahan metode kerja kontraktor. Berdasarkan item tersebut dan gambar shopdrawing dilanjutkan dengan menguraikan pekerjaan yang mengalami rework dengan lebih detail, kemudian dilakukan perhitungan volumenya. Untuk analisa harga satuan digunakan harga kontrak yang telah disepakati antara kontraktor dengan pihak owner. Hasil dari estimasi biaya yang dilakukan diperoleh hasil penyebab rework berturut-turut adalah kurangnya komunikasi sebesar Rp. 140.654.089 atau 54,4\%, perubahan desain Rp. 111.540 .625 atau 43,1\%, dan kesalahan metode kerja Rp. 6.454.495 atau 2,5\%.
\end{abstract}

Kata kunci: pekerjaan arsitektur, estimasi biaya, rework 


\section{Pendahuluan}

Rework merupakan salah satu permasalahan proyek yang terjadi pada tahap pelaksanaan pekerjaan. Dengan terjadinya rework tentu mengakibatkan beberapa kerugian, seperti biaya, waktu, kualitas pekerjaan, dan menurunnya motivasi kerja. Berbagai macam penyebab adanya rework, seperti kesalahan perencanaan, kesalahan metode kerja kerja, kurangnya pengawasan, dan akibat kurangnya komunikasi antar stakeholder proyek (Rizal, 2018). Hal ini terjadi tidak hanya disebabkan oleh salah satu pihak dalam proyek. Oleh karena itu perlu dilakukan identifikasi penyebab rework, sehingga dapat diketahui pihak yang bertanggung jawab. Rework yang terjadi akibat kesalahan dalam desain perencanaan tentu yang bertanggung jawab adalah pihak konsultan perencana, adanya change order yang bertanggung jawab adalah kontraktor, kurangnya kontrol, kesalahan material, kesalahan metode kerja dan komunikasi maka yang bertanggung jawab adalah kontraktor. Karena rework ini terjadi pada tahap pelaksanaan pekerjaan maka yang paling banyak bertanggung jawab adalah dari pihak kontraktor pelaksana sebanyak $79.16 \%$ (Herdianto, 2015).

Berdasarkan penelitian Juliana (2011), rework di lapangan paling sering terjadi pada pekerjaan arsitektur/finishing, apalagi dalam satu proyek melibatkan banyak kontraktor, seperti kontraktor utama yang mengerjakan pekerjaan struktur dan arsitektur, kontraktor Mekanikal, Elektikal dan Plumbing (MEP), kontraktor Interior, kontraktor Landscape. Semakin banyak disiplin ilmu yang terlibat, maka komunikasi semakin harus intensif dilakukan, guna mencegah terjadinya kesalahpahaman dalam melaksanakan pekerjaan. Penelitian Chundawan (2014), juga menyebutkan pekerjaan yang paling sering mengalami rework adalah finishing. Pekerjaan selanjutnya adalah Mekanikal Elektrikal. Hal ini akan meningkatkan biaya pelaksanaan item pekerjaan yaitu biaya awal ditambah biaya penyelesaian rework. Selain itu rework sudah pasti akan memperpanjang waktu penyelesaian yang apabila berada pada lintasan kritis dapat berakibat keterlambatan pekerjaan (Rahardjo \& Wiguna, 2011). Berdasarkan penelitian Hamid (2019) teridentifikasi 5 faktor penyebab terjadinya rework yaitu faktor manajerial, faktor metoda pelaksanaan konstruksi, faktor material, faktor sumber daya manusia dan faktor site conditions. Faktor yang paling dominan penyebab rework adalah faktor manajerial, pada sub faktor kurangnya kerja sama tim (teamwork). Faktor dominan kesalahan gambar menimbulkan pengaruh yang signifikan terhadap pekerjaan ulang finishing (Prianto, 2014).

Pada pembangunan salah satu hotel di kawasan Uluwatu, banyak terjadi rework yang disebabkan oleh kesalahan komunikasi antar kontraktor, kesalahan metode kerja, kesalahan pembacaan gambar, dan perubahan desain. Oleh karena itu perlu dilakukan identifikasi lebih lanjut tentang item pekerjaan yang mengalami rework dan melakukan analisis besarnya biaya akibat adanya rework. Pekerjaan bongkar pasang plafond dan keramik lantai merupakan salah satu contoh kesalahan komunikasi antar kontraktor, bongkar pasang lantai parquet disebabkan karena kesalahan metode pemasangan, bongkar pasang dinding akibat perubahan disain oleh konsultan.

\section{Metodologi}

Penelitian terdahulu tentang rework sudah banyak dilakukan, namun hanya sebatas menentukan penyebab dan yang bertanggung jawab terhadap rework tersebut. Besarnya biaya yang terjadi akibat permasalahan tersebut belum pernah dilakukan analisis. Oleh karena itu, pada penelitian ini menganalisis besarnya biaya yang dikeluarkan akibat adanya rework.

Penelitian dilakukan pada salah satu pembangunan Hotel di area Uluwatu yang sedang mengerjakan pekerjaan Arsitektur, dan ME. Penelitian ini diawali dengan melakukan wawancara dengan pihak kontraktor dan konsultan Manajemen Konstruksi. Pengumpulan responden menggunakan metode purposive sampling atau pemilihan secara sengaja, karena tidak semua unsur masyarakat dan institusi memahami dan terlibat secara langsung dalam pekerjaan konstruksi. Responden yang diambil adalah pihak-pihak yang terlibat dalam pelaksanaan konstruksi, yaitu project manager, supervisor, quantity surveyor, quality control, konsultan MK. Jumlah responden yang dipilih pada proyek tersebut adalah 10 responden, 
terdiri dari project manager 1 orang, supervisor 4 orang, quantity surveyor 1 orang, quality control 1 orang, konsultan MK 3 orang. Metode wawancara yang digunakan adalah terstruktur, disiapkan petanyaan-pertanyaan yang tertuang dalam form wawancara. Adapun isi dari form wawancara adalah sebagai berikut:

Tabel 1 Isi form wawancara

\begin{tabular}{|l|l|l|}
\hline No & \multicolumn{1}{|c|}{ Pertanyaan } & Jawaban \\
\hline 1 & Apa saja skup pekerjaan arsitektur yang sudah dikerjakan? & \\
\hline 2 & $\begin{array}{l}\text { Apakah ada item pekerjaan arsitektur yang sudah dilaksanakan mengalami } \\
\text { bongkar pasang ulang/ rework? }\end{array}$ & \\
\hline 3 & $\begin{array}{l}\text { Mohon disebutkan item-item pekerjaan yang sudah dilaksanakan mengalami } \\
\text { bongkar pasang ulang/ rework? }\end{array}$ & \\
\hline 4 & Apa penyebab terjadinya permasalahan bongkar pasang tersebut? & \\
\hline 5 & $\begin{array}{l}\text { Apakah dari pihak konsultan MK mengeluarkan site instruction untuk pekerjaan- } \\
\text { pekerjaan tersebut? }\end{array}$ & \\
\hline 6 & Apakah semua pekerjaan-pekerjaan tersebut ada shopdrawing? & \\
\hline
\end{tabular}

Dari hasil wawancara akan diperoleh item-item pekerjaan yang mengalami rework. Selanjutnya adalah melakukan perhitungan atau melakukan estimasi biaya terhadap item-item tersebut. Data yang diperlukan adalah berupa gambar shopdrawing sebelum dan setelah dilakukan rework. Estimasi diawali dengan mengelompokkan item pekerjaan berdasarkan site instruction yang dikeluarkan oleh konsultan MK. Selanjutnya melakukan perhitungan volume pekerjaan dan menyusun RAB. Untuk analisa harga satuan digunakan harga satuan kontrak. Perhitungan yang dilakukan adalah menghitung biaya langsung proyek.

\section{Elemen Biaya Proyek}

Untuk pekerjaan pembangunan konstruksi, pada umumnya elemen-elemen biaya yang harus diperhitungkan meliputi :

a. Biaya Langsung (Direct Cost)

Biaya langsung merupakan biaya-biaya yang langsung berhungan dengan pekerjaan pembangunan, dan besarnya hampir selalu berbanding lurus dengan volume pekerjaan tersebut. Artinya semakin besar volume pekerjaannya, semakin besar pula biaya langsung, atau sebaliknya. Adapun yang termasuk biaya langsung adalah biaya upah, biaya bahan, biaya peralatan, biaya subkontraktor.

b. Biaya Tak Langsung (Indirect Cost)

Biaya tidak langsung proyek atau disebut juga overhead ialah biaya tambahan yang harus dikeluarkan dalam pelaksanaan kegiatan atau pekerjaan namun tidak berhubungan langsung dengan biaya bahan, peralatan dan tenaga kerja. Yang termasuk biaya tak langsung adalah biaya umum lapangan yang meliputi biaya persiapan lapangan, pembuatan pagar dan papan nama proyek, pembuat site office, biaya operasional kendaraan yang melayani proyek, gaji mandor, dan gaji pengawas lapangan. Biaya umum kantor yang meliputi seluruh biaya operasional kantor yang terdiri dari biaya pemeliharaan kantor, pembelian peralatan habis pakai, gaji pegawai, biaya komunikasi dan utilitas. Biaya umum kantor ini tidak seluruhnya dibebankan pada satu proyek, melainkan dibebankan secara proporsional pada seluruh proyek yang sedang ditangani (dalam waktu yang bersamaan).

\section{Langkah-Langkah Menyusun RAB}

Rencana Anggaran Biaya (RAB) adalah suatu gambaran banyaknya biaya yang dibutuhkan baik upah maupun bahan dalam sebuah pekerjaan proyek konstruksi, membangun rumah, atau meningkatkan rumah, gedung, jembatan, atau bangunan lainnya (Pahlevi \& Sari, 2020). 
Dalam menyusun RAB data yang harus ada minimal adalah gambar dan spesifikasi teknis. Adapun langkah-langkah dalam menyusun RAB:

a. Mempelajari gambar dan spesifikasi. Dari gambar dan spesifikasi dapat disusun daftar seluruh jenis pekerjaan yang ada.

b. Membuat pengelompokkan jenis pekerjaan. Tujuan pengelompokan jenis pekerjaan ini adalah untuk membuat daftar seluruh jenis pekerjaan yang ada serta membuat kelompok-kelompok pekerjaan yang sejenis/tipikal sekaligus menetapkan satuannya sehingga kemungkinan adanya pekerjaan yang tertinggal dan tidak terhitung volumenya menjadi lebih kecil dan kemungkinan terjadinya kesalahan di dalam mengestimasi harga bangunan dapat dihindarkan. Disamping itu juga dapat mempermudah perhitungan volume dan harga satuan untuk masing-masing jenis pekerjaan.

c. Menghitung volume pekerjaan. Berdasarkan hasil pengelompokan dan pemilihan satuan, selanjutnya dapat dihitung volume masing-masing jenis pekerjaan dengan melihat, meneliti dan memahami gambar-gambar rencana serta RKS untuk bangunan yang bersangkutan.

d. Menyusun analisa harga satuan. Analisa harga satuan bahan, alat, dan tenaga kerja dilakukan dengan menghitung setiap elemen biaya untuk satu satuan yang telah dipilih. Setelah masing-masing harga satuan bahan, alat, dan tenaga kerja terhitung, selanjutnya disusun daftar harga satuan, alat, dan tenaga kerja. Selanjutnya dengan berdasarkan satuan masing-masing pekerjaan dan dengan data harga satuan bahan, alat, dan tenaga kerja, disusun analisa harga satuan pekerjaan.

\section{Jenis-Jenis Item Pekerjaan yang Mengalami Rework pada Penelitian Sebelumnya}

Berdasarkan penelitian sebelumnya yang mengkaji pekerjaan rework, berikut item pekerjaan arsitektur yang mengalami rework:

Tabel 2 Penelitian terdahulu

\begin{tabular}{|c|l|l|l|}
\hline No & Item yang Mengalami Rework & \multicolumn{1}{|c|}{ Penyebab } & \multicolumn{1}{c|}{ Sumber } \\
\hline 1 & Pekerjaan Pasangan & kesalahan metode kerja & (Rahardjo, 2011) \\
\hline 2 & Pekerjaan Plesteran dan Benangan & kesalahan metode kerja & (Rahardjo, 2011) \\
\hline 3 & Pekerjaan Kusen Pintu dan Jendela & kesalahan metode kerja & $\begin{array}{l}\text { (Rahardjo, 2011), } \\
\text { (Herdianto, 2015) }\end{array}$ \\
\hline 4 & Pekerjaan Lantai & kesalahan metode kerja & $\begin{array}{l}\text { (Rahardjo, 2011), } \\
\text { (Herdianto, 2015) }\end{array}$ \\
\hline 5 & Pekerjaan Pengecatan & kesalahan metode kerja & $\begin{array}{l}\text { (Rahardjo, 2011), } \\
\text { (Wongso, 2019) }\end{array}$ \\
\hline 6 & Kesalahan dalam pemasangan plafond & buruknya alur informasi & (Herdianto, 2015) \\
\hline 7 & & buruknya alur informasi & (Herdianto, 2015) \\
\hline
\end{tabular}

Diperoleh 7 item pekerjaan yang sering mengalami rework pada pekerjaan arsitektur, yaitu pekerjaan pasangan, pekerjaan plesteran dan benangan, pekerjaan kusen pintu dan jendela, pekerjaan lantai, pekerjaan pengecatan, pekerjaan plafond, pekerjaan dinding.

\section{Hasil dan Pembahasan}

\section{Hasil Wawancara}

Melalui wawancara terstruktur dengan 10 orang responden yang dipilih dengan metode purposive sampling diperoleh item-item pekerjaan finishing yang mengalami rework sampai pada progress proyek sebesar $85 \%$. Berikut item pekerjaan yang mengalami rework dan penyebabnya. 
JURNAL REKAYASA KONSTRUKSI MEKANIKA SIPIL (JRKMS)

Volume 04 Nomor 01 Mei $2021 \quad$ p-ISSN 2614-5707 e-ISSN 2715-1581

Tabel 3 Item - item pekerjaan yang mengalami rework dan penyebabnya

\begin{tabular}{|c|c|c|c|}
\hline No & Item yang Mengalami Rework & Penyebab & SI \\
\hline 1 & Pekerjaan perbaikan plafond koridor, Block B,C, GM Office & $\begin{array}{l}\text { Kurangnya } \\
\text { komunikasi }\end{array}$ & 205 \\
\hline 2 & $\begin{array}{l}\text { Pekerjaan perbaikan bongkar keramik lantai Ruang Accounting, } \\
\text { GM Office }\end{array}$ & $\begin{array}{l}\text { Kurangnya } \\
\text { komunikasi }\end{array}$ & 205 \\
\hline 3 & Pekerjaan perbaikan dinding plester aci area GM Office, $\mathrm{BOH}$ & $\begin{array}{l}\text { Kurangnya } \\
\text { komunikasi }\end{array}$ & 205 \\
\hline 4 & Pekerjaan perbaikan rangka ceiling Bihua area GM Office & $\begin{array}{l}\text { Kurangnya } \\
\text { komunikasi }\end{array}$ & 261 \\
\hline 5 & Pekerjaan perbaikan bongkar keramik lantai koridor $\mathrm{BOH}$ & $\begin{array}{l}\text { Kurangnya } \\
\text { komunikasi }\end{array}$ & 261 \\
\hline 6 & $\begin{array}{l}\text { Perbaikan dinding finish aci area tangga FOH, GM Office, BOH, } \\
\text { F\&B Store, Staff Canteen, Uniform, Locker Male,HR, } \\
\text { Multifunction Room, Pantry Office (FOH), Pool Bar }\end{array}$ & $\begin{array}{l}\text { Kurangnya } \\
\text { komunikasi }\end{array}$ & 261 \\
\hline 7 & Pekerjaan perbaikan lantai terazzo area Multifunction & $\begin{array}{l}\text { Kurangnya } \\
\text { komunikasi }\end{array}$ & 261 \\
\hline 8 & Perbaikan lantai nero absoluto area Lobby & $\begin{array}{l}\text { Kurangnya } \\
\text { komunikasi }\end{array}$ & 261 \\
\hline 9 & Perbaikan plafond area Corridor Lift PL 1A, Block G\& H, A,B,D & $\begin{array}{l}\text { Kurangnya } \\
\text { komunikasi }\end{array}$ & 261 \\
\hline 10 & Pekerjaan bongkar/pasang lantai parquet area Block A,B,H & $\begin{array}{l}\text { Kurangnya } \\
\text { komunikasi }\end{array}$ & 261 \\
\hline 11 & $\begin{array}{l}\text { Perbaikan pasangan batu kali random area Landscape, koridor } \\
\text { Public Area }\end{array}$ & $\begin{array}{l}\text { Kurangnya } \\
\text { komunikasi }\end{array}$ & 261 \\
\hline 12 & $\begin{array}{l}\text { Perbaikan plafond Public Toilet, Block G, Block A Suite two } \\
\text { Buys, Block D, Korridor BOH }\end{array}$ & $\begin{array}{l}\text { Kurangnya } \\
\text { komunikasi }\end{array}$ & 323 \\
\hline 13 & $\begin{array}{l}\text { Pekerjaan lantai parquet block G, Block A Suite two Buys,Block } \\
\text { D }\end{array}$ & $\begin{array}{l}\text { Kurangnya } \\
\text { komunikasi }\end{array}$ & 323 \\
\hline 14 & $\begin{array}{l}\text { Pekerjaan bongkaran dinding bata ringan suite room termasuk } \\
\text { kolom dan balok praktis }\end{array}$ & $\begin{array}{l}\text { Perubahan } \\
\text { desain }\end{array}$ & 34 \\
\hline 15 & $\begin{array}{l}\text { Pekerjaan bongkaran dinding bata ringan finish plaster lantai } 3 \\
\text { termasuk kolom dan balok praktis Block F,G,C,D,H }\end{array}$ & $\begin{array}{l}\text { Perubahan } \\
\text { desain }\end{array}$ & 34 \\
\hline 16 & Pekerjaan plesteran dinding bata ringan lantai 3 block F,G,C,D,H & $\begin{array}{l}\text { Perubahan } \\
\text { desain }\end{array}$ & 34 \\
\hline 17 & Pekerjaan struktur bathub handicaped room & $\begin{array}{l}\text { Perubahan } \\
\text { desain }\end{array}$ & 34 \\
\hline 18 & Pekerjaan Artwork & $\begin{array}{l}\text { Kesalahan } \\
\text { metode kerja }\end{array}$ & 280 \\
\hline 19 & Pekerjaan lantai parquet Block A,B,H lantai 3 & $\begin{array}{l}\text { Kesalahan } \\
\text { metode kerja }\end{array}$ & 280 \\
\hline 20 & Perubahan finishing toping sunken lounge & $\begin{array}{l}\text { Perubahan } \\
\text { desain }\end{array}$ & 260 \\
\hline
\end{tabular}

Berdasarkan tabel di atas diperoleh 20 item pekerjaan yang mengalami rework, diantaranya adalah pekerjaan plafond, dinding, lantai, pekerjaan artwork, toping sunken lounge. Dari 20 item tersebut, 13 pekerjaan disebabkan oleh kurangnya komunikasi antar kontraktor, 5 pekerjaan disebabkan adanya perubahan desain dari perencana, dan 2 pekerjaan disebabkan oleh kesalahan metode kerja kontraktor. Kurangnya komunikasi antar kontraktor adalah kesalahan dalam menerima informasi yang disampaikan. Perubahan disain oleh perencana adalah pekerjaan lapangan yang telah dikerjakan sesuai desain awal namun setelah terpasang dilakukan perubahan oleh konsultan sehingga harus dibongkar ulang. Kesalahan metode kerja adalah disebabkan oleh kelalaian dalam pengawasan pekerjaan yang dikerjakan oleh kontraktor. Berikut perbandingan penyebab rework dan item pekerjaannya. 
JURNAL REKAYASA KONSTRUKSI MEKANIKA SIPIL (JRKMS)

Volume 04 Nomor 01 Mei 2021

p-ISSN 2614-5707 e-ISSN 2715-1581

Tabel 4 Perbandingan penyebab rework dan item pekerjaannya

\begin{tabular}{|l|c|r|}
\hline Penyebab Rework & Jumlah item & Persentase \% \\
\hline Kurangnya komunikasi & 13 & $65 \%$ \\
\hline Perubahan desain & 5 & $25 \%$ \\
\hline Kesalahan metode kerja & 2 & $10 \%$ \\
\hline Total & 20 & $100 \%$ \\
\hline
\end{tabular}

Selanjutnya item-item tersebut dibuatkan estimasi biayanya. Tahap pertama dengan menguraikan pekerjaan berdasarkan nomor SI yang diperoleh, selanjutnya menghitung volume pekerjaan, dan memasukkan analisa harga satuan.

\section{Estimasi Biaya Langsung Pekerjaan Rework}

Item pekerjaan yang diperoleh berdasarkan wawancara dilanjutkan dengan membandingkan gambar shopdrawing yang diperoleh, untuk dibuatkan detail item pekerjaan dan volumenya. Harga satuan yang dimasukkan dalam analisis ini adalah analisa harga satuan kontrak yang telah disepekati antara kontraktor utama dengan owner estimate (OE). Berikut estimasi biaya pekerjaan rework:

Tabel 5 Estimasi Biaya Langsung Pekerjaan Rework

\begin{tabular}{|c|c|c|c|c|c|}
\hline No. & Uraian & Unit & Qty & $\begin{array}{l}\text { Harga } \\
(\mathbf{R p})\end{array}$ & $\begin{array}{c}\text { Jumlah } \\
\text { Harga } \\
\text { (Rp) }\end{array}$ \\
\hline \multicolumn{6}{|c|}{ SI NOMOR 34 (PERUBAHAN DESAIN) } \\
\hline \multirow[t]{3}{*}{1} & Block H & & & & \\
\hline & $\begin{array}{l}\text { Pekerjaan bongkaran dinding bata ringan suite room } \\
\text { termasuk kolom dan balok praktis akibat perubahan } \\
\text { desain. }\end{array}$ & $\mathrm{m}^{2}$ & 219,12 & 69.640 & 15.259 .517 \\
\hline & $\begin{array}{l}\text { Pekerjaan pemasangan dinding bata ringan suite room } \\
\text { termasuk balok dan kolom praktis sesuai dengan gambar } \\
\text { email. }\end{array}$ & $\mathrm{m}^{2}$ & 302,87 & 158.300 & 47.944 .408 \\
\hline \multirow[t]{4}{*}{2} & Block F \& G & & & & \\
\hline & $\begin{array}{l}\text { Pekerjaan bongkaran dinding bata ringan finish plaster } \\
\text { lantai } 3 \text { termasuk kolom dan balok praktis akibat } \\
\text { perubahan posisi pintu sliding. }\end{array}$ & $\mathrm{m}^{2}$ & 62,54 & 69.640 & 4.355 .286 \\
\hline & $\begin{array}{l}\text { Pekerjaan pemasangan dinding bata ringan lantai } 3 \\
\text { termasuk balok dan kolom praktis sesuai dengan } \\
\text { perubahan posisi pintu sliding. }\end{array}$ & $\mathrm{m}^{2}$ & 62,54 & 158.300 & 9.900 .082 \\
\hline & $\begin{array}{l}\text { Pekerjaan plesteran dinding bata ringan lantai } 3 \text { akibat } \\
\text { perubahan posisi pintu sliding. }\end{array}$ & $\mathrm{m}^{2}$ & 62,54 & 83.300 & 5.209 .582 \\
\hline \multirow[t]{3}{*}{3} & Block C & & & & \\
\hline & $\begin{array}{l}\text { Pekerjaan bongkaran dinding bata ringan lantai } 3 \\
\text { termasuk kolom dan balok praktis akibat perubahan } \\
\text { posisi pintu sliding. }\end{array}$ & $\mathrm{m}^{2}$ & 31,27 & 69.640 & 2.177 .643 \\
\hline & $\begin{array}{l}\text { Pekerjaan pemasangan dinding bata ringan lantai } 3 \\
\text { termasuk balok dan kolom praktis sesuai dengan } \\
\text { perubahan posisi pintu sliding. }\end{array}$ & $\mathrm{m}^{2}$ & 31,27 & 158.300 & 4.950 .041 \\
\hline \multirow[t]{4}{*}{4} & Block D & & & & \\
\hline & $\begin{array}{l}\text { Pekerjaan bongkaran dinding bata ringan finish plaster } \\
\text { lantai } 3 \text { termasuk kolom dan balok praktis akibat } \\
\text { perubahan posisi pintu sliding. }\end{array}$ & $\mathrm{m}^{2}$ & 31,27 & 69.640 & 2.177 .643 \\
\hline & $\begin{array}{l}\text { Pekerjaan pemasangan dinding bata ringan lantai } 3 \\
\text { termasuk balok dan kolom praktis sesuai dengan } \\
\text { perubahan posisi pintu sliding. }\end{array}$ & $\mathrm{m}^{2}$ & 31,27 & 158.300 & 4.950 .041 \\
\hline & $\begin{array}{l}\text { Pekerjaan plesteran dinding bata ringan lantai } 3 \text { akibat } \\
\text { perubahan posisi pintu sliding. }\end{array}$ & $\mathrm{m}^{2}$ & 31,27 & 83.300 & 2.604 .791 \\
\hline 5 & Block H & & & & \\
\hline
\end{tabular}


JURNAL REKAYASA KONSTRUKSI MEKANIKA SIPIL (JRKMS)

Volume 04 Nomor 01 Mei $2021 \quad$ p-ISSN 2614-5707 e-ISSN 2715-1581

\begin{tabular}{|c|c|c|c|c|c|}
\hline No. & Uraian & Unit & Qty & $\begin{array}{c}\text { Harga } \\
(\mathbf{R p})\end{array}$ & $\begin{array}{l}\text { Jumlah } \\
\text { Harga } \\
(\text { Rp) }\end{array}$ \\
\hline & $\begin{array}{l}\text { Pekerjaan bongkaran dinding bata ringan finish plaster } \\
\text { lantai } 3 \text { termasuk kolom dan balok praktis akibat } \\
\text { perubahan posisi pintu sliding. }\end{array}$ & $\mathrm{m}^{2}$ & 15,635 & 158.300 & 2.475 .021 \\
\hline & $\begin{array}{l}\text { Pekerjaan pemasangan dinding bata ringan lantai } 3 \\
\text { termasuk balok dan kolom praktis sesuai dengan } \\
\text { perubahan posisi pintu sliding. }\end{array}$ & $\mathrm{m}^{2}$ & 15,635 & 158.300 & 2.475 .021 \\
\hline & $\begin{array}{l}\text { Pekerjaan plesteran dinding bata ringan lantai } 3 \text { akibat } \\
\text { perubahan posisi pintu sliding. }\end{array}$ & $\mathrm{m}^{2}$ & 15,635 & 83.300 & 1.302 .396 \\
\hline \multirow[t]{6}{*}{6} & Handicaped & & & & \\
\hline & Bongkaran bathub & unit & 1 & 552.500 & 552.500 \\
\hline & Bongkar struktur meja wastafel & unit & 1 & 365.800 & 365.800 \\
\hline & Pasangan dinding bata ringan area bathroom & $\mathrm{m}^{2}$ & 13,5 & 158.300 & 2.137 .050 \\
\hline & Pasang struktur meja wastafel & unit & 1 & 492.254 & 492.254 \\
\hline & TOTAL SI 34 & & & \multicolumn{2}{|r|}{109.329 .073} \\
\hline \multicolumn{6}{|c|}{ SI NOMOR 205 (KURANGNYA KOMUNIKASI) } \\
\hline \multirow[t]{2}{*}{1} & Koridor block A: & & & & \\
\hline & $\begin{array}{l}\text { Pekerjaan perbaikan plafond koridor yang sudah } \\
\text { dipasang dibuka akibat instalasi lampu tersebut belum } \\
\text { tersambung }\end{array}$ & $\mathrm{m}^{2}$ & 9,75 & 265.000 & 2.583 .750 \\
\hline \multirow[t]{2}{*}{2} & Ruang Accounting & & & & \\
\hline & $\begin{array}{l}\text { Pekerjaan perbaikan bongkar keramik lantai akibat } \\
\text { perubahan titik kabel listrik di lantai. }\end{array}$ & titik & 20 & 53.500 & 1.070 .000 \\
\hline \multirow[t]{2}{*}{3} & GM Office & & & & \\
\hline & $\begin{array}{l}\text { Pekerjaan perbaikan dinding plester aci dengan } \\
\text { pemasangan kawat ayam akibat bobokan sparingan } \\
\text { listrik. }(76,4 \mathrm{~m})\end{array}$ & titik & 29 & 355.000 & 10.295 .000 \\
\hline \multirow[t]{2}{*}{4} & $\mathrm{BOH}$ & & & & \\
\hline & $\begin{array}{l}\text { Perbaikan bobokan dinding yang sudah diplaster, aci, cat } \\
\text { untuk sparing conduit. }\end{array}$ & titik & 42 & 355.000 & 14.910 .000 \\
\hline \multirow[t]{2}{*}{5} & Block B & & & & \\
\hline & $\begin{array}{l}\text { Perbaikan kerusakan plafond sampai cat finish bedroom } \\
\text { akibat pekerjaan ME }\end{array}$ & titik & 1 & 455.000 & 455.000 \\
\hline \multirow[t]{4}{*}{6} & GM Office & & & & \\
\hline & $\begin{array}{l}\text { Pekerjaan perbaikan dinding plester aci dengan } \\
\text { pemasangan kawat ayam akibat bobokan sparingan listrik }\end{array}$ & titik & 6 & 355.000 & 2.130 .000 \\
\hline & $\begin{array}{l}\text { Pekerjaan perbaikan dinding plester aci dengan } \\
\text { pemasangan kawat ayam akibat bobokan stop contact } \\
\text { listrik }\end{array}$ & titik & 5 & 355.000 & 1.775 .000 \\
\hline & $\begin{array}{l}\text { Pekerjaan perbaikan bongkar keramik lantai untuk } \\
\text { sparing drain AC }\end{array}$ & titik & 5 & 53.500 & 267.500 \\
\hline \multirow[t]{2}{*}{7} & Block C & & & & \\
\hline & $\begin{array}{l}\text { Perbaikan kerusakan plafond sampai cat finish balcony } \\
\text { akibat pekerjaan pemasangan kabel sensor ME }\end{array}$ & titik & 12 & 455.000 & 5.460 .000 \\
\hline \multirow[t]{3}{*}{8} & GM Office & & & & \\
\hline & $\begin{array}{l}\text { Perbaikan rangka plafond yang sudah terpasang akibat } \\
\text { pekerjaan } \mathrm{ME}\end{array}$ & $\mathrm{m}^{2}$ & 24,21 & 87.500 & 2.118 .375 \\
\hline & TOTAL SI 205 & & & & 41.064.625 \\
\hline \multicolumn{6}{|c|}{ SI NOMOR 260 (PERUBAHAN DESAIN) } \\
\hline 1 & Bongkar batu candi Sunken Lounge & $\mathrm{m}^{2}$ & 6,72 & 65.000 & 436.800 \\
\hline \multirow[t]{2}{*}{2} & Pasang pebblewash Sunken Lounge & $\mathrm{m}^{2}$ & 6,72 & 264.100 & 1.774 .752 \\
\hline & TOTAL SI 260 & & & & 2.211.552 \\
\hline
\end{tabular}


JURNAL REKAYASA KONSTRUKSI MEKANIKA SIPIL (JRKMS)

Volume 04 Nomor 01 Mei $2021 \quad$ p-ISSN 2614-5707 e-ISSN 2715-1581

\begin{tabular}{|c|c|c|c|c|c|}
\hline No. & Uraian & Unit & Qty & $\begin{array}{l}\text { Harga } \\
(\mathbf{R p})\end{array}$ & $\begin{array}{c}\text { Jumlah } \\
\text { Harga } \\
\text { (Rp) }\end{array}$ \\
\hline \multicolumn{6}{|c|}{ SI NOMOR 261 (KURANGNYA KOMUNIKASI) } \\
\hline \multirow[t]{2}{*}{1} & GM Office & & & & \\
\hline & $\begin{array}{l}\text { Pekerjaan perbaikan rangka ceiling Bihua area GM } \\
\text { Office }\end{array}$ & ttk & 6 & 165.000 & 990.000 \\
\hline \multirow[t]{3}{*}{2} & Koridor $\mathrm{BOH}$ & & & & \\
\hline & $\begin{array}{l}\text { Bongkar pasang keramik lantai akibat bobokan sparing } \\
\text { drain AC }\end{array}$ & unit & 29 & 100.000 & 2.900 .000 \\
\hline & $\begin{array}{l}\text { Bongkar pasang keramik plin akibat bobokan sparing } \\
\text { drain AC }\end{array}$ & $\mathrm{m}^{\prime}$ & 8,4 & 80.000 & 672.000 \\
\hline \multirow[t]{2}{*}{3} & Tangga FOH & & & & \\
\hline & $\begin{array}{l}\text { Perbaikan dinding finish aci akibat pemasangan kabel } \\
\text { konduit }\end{array}$ & $\mathrm{m}^{\prime}$ & 18,2 & 150.000 & 2.730 .000 \\
\hline \multirow[t]{2}{*}{4} & Multifunction (External) & & & & \\
\hline & $\begin{array}{l}\text { Pekerjaan perbaikan lantai terazo akibat pemindahan } \\
\text { jalur kabel. }\end{array}$ & ttk & 3 & 343.541 & 1.030 .624 \\
\hline \multirow[t]{3}{*}{5} & GM Office & & & & \\
\hline & $\begin{array}{l}\text { Pekerjaan perbaikan bobokan dinding akibat sparing } \\
\text { listrik }\end{array}$ & $\mathrm{m}^{\prime}$ & 1,35 & 150.000 & 202.500 \\
\hline & Perbaikan kermaik lantai & unit & 1 & 100.000 & 100.000 \\
\hline \multirow[t]{2}{*}{6} & Lobby & & & & \\
\hline & Perbaikan bobokan balok untuk jalur springkler. & ttk & 18 & 250.000 & 4.500 .000 \\
\hline \multirow[t]{2}{*}{7} & Lobby & & & & \\
\hline & $\begin{array}{l}\text { Perbaikan lantai nero absoluto akibat kesalahan } \\
\text { pemasangan kabel. }\end{array}$ & ttk & 3 & 380.000 & 1.140 .000 \\
\hline \multirow[t]{2}{*}{8} & $\mathrm{BOH}$ & & & & \\
\hline & $\begin{array}{l}\text { Perbaikan bobokan dinding akibat pemasangan sparingan } \\
\text { conduit drain AC. }\end{array}$ & m' & 33,7 & 150.000 & 5.055 .000 \\
\hline \multirow[t]{2}{*}{9} & F\&B Store & & & & \\
\hline & $\begin{array}{l}\text { Perbaikan bobokan dinding akibat pemasangan sparingan } \\
\text { conduit drain AC. }\end{array}$ & m' & 7,95 & 150.000 & 1.192 .500 \\
\hline \multirow[t]{2}{*}{10} & Staff Canteen & & & & \\
\hline & $\begin{array}{l}\text { Perbaikan bobokan dinding akibat pemasangan sparingan } \\
\text { conduit. }\end{array}$ & $\mathrm{m}$ & 22,1 & 150.000 & 3.315 .000 \\
\hline \multirow[t]{2}{*}{11} & Corridor Lift PL 1A & & & & \\
\hline & Perbaikan rangka ceiling & ttk & 4 & 165.000 & 660.000 \\
\hline \multirow[t]{2}{*}{12} & Block G\& H & & & & \\
\hline & Perbaikan plafond akibat pemindahan head springler & ttk & 5 & 165.000 & 825.000 \\
\hline \multirow[t]{2}{*}{13} & Block H & & & & \\
\hline & Perbaikan plafond akibat pemindahan head springler & ttk & 5 & 165.000 & 825.000 \\
\hline \multirow[t]{2}{*}{14} & Uniform, Locker Male,HR & & & & \\
\hline & $\begin{array}{l}\text { Perbaikan bobokan dinding akibat pemasangan sparingan } \\
\text { conduit dan pipa drain AC. }\end{array}$ & $\mathrm{m}^{\prime}$ & 2,7 & 150.000 & 405.000 \\
\hline \multirow[t]{2}{*}{15} & Multifunction Room & & & & \\
\hline & $\begin{array}{l}\text { Perbaikan bobokan dinding akibat pemasangan sparingan } \\
\text { conduit dan pipa drain AC. }\end{array}$ & $\mathrm{m}^{\prime}$ & 5,148 & 150.000 & 772.200 \\
\hline \multirow[t]{2}{*}{16} & Block H & & & & \\
\hline & Perbaikan plafond akibat pekerjaan ME & ttk & 87 & 165.000 & 14.355 .000 \\
\hline \multirow[t]{2}{*}{17} & Block D & & & & \\
\hline & Perbaikan plafond akibat pemasangan springkler & ttk & 14 & 165.000 & 2.310 .000 \\
\hline
\end{tabular}


JURNAL REKAYASA KONSTRUKSI MEKANIKA SIPIL (JRKMS)

Volume 04 Nomor 01 Mei $2021 \quad$ p-ISSN 2614-5707 e-ISSN 2715-1581

\begin{tabular}{|c|c|c|c|c|c|}
\hline No. & Uraian & Unit & Qty & $\begin{array}{c}\text { Harga } \\
(\mathbf{R p})\end{array}$ & $\begin{array}{c}\text { Jumlah } \\
\text { Harga } \\
\text { (Rp) }\end{array}$ \\
\hline \multirow[t]{2}{*}{18} & Block A\&B & & & & \\
\hline & Perbaikan plafond akibat pemasangan springkler & ttk & 30 & 165.000 & 4.950 .000 \\
\hline \multirow[t]{2}{*}{19} & Block G & & & & \\
\hline & Perbaikan plafond akibat pemasangan springkler & ttk & 28 & 165.000 & 4.620 .000 \\
\hline \multirow[t]{2}{*}{20} & $\mathrm{BOH}$ & & & & \\
\hline & Perbaikan dinding area $\mathrm{BOH}$ akibat pekerjaan $\mathrm{ME}$ & ttk & 21 & 285.000 & 5.985 .000 \\
\hline \multirow[t]{2}{*}{21} & Block A,B,H & & & & \\
\hline & $\begin{array}{l}\text { Pekerjaan bongkar/pasang lantai parquet akibat } \\
\text { pergeseran outlet. }\end{array}$ & $\mathrm{m}^{2}$ & 7 & 720.000 & 5.040 .000 \\
\hline \multirow[t]{2}{*}{22} & Block A & & & & \\
\hline & Perbaikan plafond akibat pemasangan springkler & ttk & 6 & 165.000 & 990.000 \\
\hline \multirow[t]{2}{*}{23} & Pantry Office $(\mathrm{FOH})$ & & & & \\
\hline & Perbaikan bobokan dinding akibat pekerjaan ME. & $\mathrm{m}^{\prime}$ & 12 & 150.000 & 1.800 .000 \\
\hline \multirow[t]{2}{*}{24} & Depan Block H-Landscape & & & & \\
\hline & $\begin{array}{l}\text { Perbaikan pasangan batu kali random akibat jalur pipa } \\
\text { Hydrant. }\end{array}$ & ttk & 8 & 445.000 & 3.560 .000 \\
\hline \multirow[t]{2}{*}{25} & Koridor Public Area & & & & \\
\hline & $\begin{array}{l}\text { Bongkaran batu granite dinding akibat kabel yang } \\
\text { tertinggal }\end{array}$ & ttk & 3 & 445.000 & 1.335 .000 \\
\hline \multirow[t]{3}{*}{26} & Pool Bar & & & & \\
\hline & Perbaikan dinding area Pool Bar akibat pekerjaan ME & ttk & 1 & 285.000 & 285.000 \\
\hline & TOTAL SI 261 & & & & 72.544 .824 \\
\hline \multicolumn{6}{|c|}{ SI NOMOR 280 (KESALAHAN METODE KERJA) } \\
\hline 1 & Pekerjaan waterproofing membrane & $\mathrm{m}^{2}$ & 3,30 & 98.600 & 325.380 \\
\hline 2 & Screed proteksi waterproofing & $\mathrm{m}^{2}$ & 3,30 & 59.792 & 197.315 \\
\hline 3 & Grouting pipa & ttk & 1,00 & 50.000 & 50.000 \\
\hline 4 & $\begin{array}{l}\text { Urugan bata ringan }+ \text { pasir termasuk langsir dan } \\
\text { pemadatan }\end{array}$ & unit & 1,00 & 350.000 & 350.000 \\
\hline 5 & Beton tebal $100 \mathrm{~mm}$ & unit & 1,00 & 235.000 & 235.000 \\
\hline 6 & Pemasangan M7 & unit & 1,00 & 95.800 & 95.800 \\
\hline 7 & Pekerjaan bongkaran parquete & $\mathrm{m}^{2}$ & 7,00 & 65.000 & 455.000 \\
\hline \multirow[t]{2}{*}{8} & Pekerjaan pemasangan parquete TEKA & $\mathrm{m}^{2}$ & 7,00 & 678.000 & 4.746 .000 \\
\hline & TOTAL SI 280 & & & & 6.454.495 \\
\hline \multicolumn{6}{|c|}{ SI NOMOR 323 (KURANGNYA KOMUNIKASI) } \\
\hline \multirow[t]{3}{*}{1} & Public Toilet & & & & \\
\hline & Bongkar kerusakan plafond akibat pengetesan AC & $\mathrm{m}^{2}$ & 4 & 75.000 & 300.000 \\
\hline & $\begin{array}{l}\text { Perbaikan plafond gypsum WR } 9 \mathrm{~mm} \text { akibat pengetesan } \\
\text { AC }\end{array}$ & $\mathrm{m}^{2}$ & 4 & 215.000 & 860.000 \\
\hline \multirow[t]{5}{*}{2} & Block G & & & & \\
\hline & Bongkar kerusakan plafond akibat pengetesan $\mathrm{AC}$ & $\mathrm{m}^{2}$ & 7,2 & 75.000 & 540.000 \\
\hline & Perbaikan plafond gypsum $12 \mathrm{~mm}$ akibat pengetesan $\mathrm{AC}$ & $\mathrm{m}^{2}$ & 7,2 & 215.000 & 1.548 .000 \\
\hline & Bongkar kerusakan parquet akibat pengetesan AC & $\mathrm{m}^{2}$ & 4,54 & 95.000 & 431.300 \\
\hline & Pergantian parquete lantai akibat pengetesan $\mathrm{AC}$ & $\mathrm{m}^{2}$ & 4,54 & 743.000 & 3.373 .220 \\
\hline \multirow[t]{2}{*}{3} & Block A Suite two Buys & & & & \\
\hline & Bongkar kerusakan plafond akibat pengetesan AC & $\mathrm{m}^{2}$ & 12 & 75.000 & 900.000 \\
\hline
\end{tabular}


JURNAL REKAYASA KONSTRUKSI MEKANIKA SIPIL (JRKMS)

Volume 04 Nomor 01 Mei $2021 \quad$ p-ISSN 2614-5707 e-ISSN 2715-1581

\begin{tabular}{|l|l|c|c|r|r|}
\hline No. & \multicolumn{1}{|c|}{ Uraian } & Unit & Qty & \multicolumn{1}{|c|}{$\begin{array}{c}\text { Harga } \\
(\text { Rp) }\end{array}$} & \multicolumn{1}{|c|}{$\begin{array}{c}\text { Jumlah } \\
\text { Harga } \\
(\text { Rp) }\end{array}$} \\
\hline & Perbaikan plafond gypsum 12 mm akibat pengetesan AC & $\mathrm{m}^{2}$ & 12 & 215.000 & 2.580 .000 \\
\hline & Bongkar kerusakan parquet akibat pengetesan AC & $\mathrm{m}^{2}$ & 12 & 95.000 & 1.140 .000 \\
\hline & Pergantian parquete lantai akibat pengetesan AC & $\mathrm{m}^{2}$ & 12 & 743.000 & 8.916 .000 \\
\hline 4 & Block D 203 & & & & \\
\hline & Bongkar kerusakan plafond akibat pengetesan AC & $\mathrm{m}^{2}$ & 4,54 & 75.000 & 340.500 \\
\hline & Perbaikan plafond gypsum 12 mm akibat pengetesan AC & $\mathrm{m}^{2}$ & 4,54 & 215.000 & 976.100 \\
\hline & Bongkar kerusakan parquet akibat pengetesan AC & $\mathrm{m}^{2}$ & 4,54 & 95.000 & 431.300 \\
\hline 5 & Pergantian parquete lantai akibat pengetesan AC & $\mathrm{m}^{2}$ & 4,54 & 743.000 & 3.373 .220 \\
\hline & Korridor BOH & & & & \\
\hline & Bongkar kerusakan plafond akibat bocornya pipa chiller & $\mathrm{m}^{2}$ & 2 & 75.000 & 150.000 \\
\hline & $\begin{array}{l}\text { Perbaikan kerusakan plafond gyptile 60x120 cm akibat } \\
\text { bocor valve pipa chiller }\end{array}$ & $\mathrm{unit}$ & 2 & 355.000 & 710.000 \\
\hline & Pembersihan dinding koridor & & & & \\
\hline & TOTAL SI 323 & $\mathrm{m}^{2}$ & 5 & 95.000 & 475.000 \\
\hline
\end{tabular}

Dari hasil analisis perhitungan estimasi biaya langsung diperoleh biaya pekerjaan yang mengalami rework berdasarkan nomor SI adalah SI nomor 34 akibat adanya perubahan desain Rp. 109.329.073,- SI Nomor 205 akibat kurangnya komunikasi Rp 41.064.625,- SI nomor 260 akibat perubahan desain Rp 2.211.552,- SI nomor 261 akibat kurangnya komunikasi Rp 72.544.823,- SI nomor 280 akibat kesalahan metode kerja Rp 6.454.494,- SI nomor 323 akibat kurangnya komunikasi Rp 27.044.640,- Apabila direkap total estimasi biaya berdasarkan penyebab dapat dilihat sepert tabel berikut:

Tabel 6 Estimasi biaya langsung berdasarkan penyebab

\begin{tabular}{|r|l|r|r|c|}
\hline \multicolumn{1}{|c|}{ No } & \multicolumn{1}{|c|}{ Penyebab Rework } & Estimasi (Rp) & Total (Rp ) & $\%$ \\
\hline 1 & SI Nomor 34 (Perubahan Desain) & 109.329 .073 & \multirow{2}{*}{111.540 .625} & \multirow{2}{*}{$43,1 \%$} \\
\hline 2 & SI Nomor 260 (Perubahan Desain) & 2.211 .552 & & \\
\hline 3 & SI Nomor 205 (Kurangnya Komunikasi) & 41.064 .625 & & \multirow{2}{*}{$54,4 \%$} \\
\hline 4 & SI Nomor 261 (Kurangnya Komunikasi) & 72.544 .824 & 140.654 .089 & \\
\hline 5 & SI Nomor 323 (Kurangnya Komunikasi) & 27.044 .640 & & \multirow{2}{*}{6.454 .495} \\
\hline 6 & SI Nomor 280 (Kesalahan Metode Kerja) & & 258.649 .209 & $100 \%$ \\
\hline
\end{tabular}

Berdasarkan tabel di atas dapat disimpulkan bahwa penyebab terjadinya rework pada pembangunan salah satu Hotel di kawasan Uluwatu adalah perubahan desain, kurangnya komunikasi, dan kessalahan metode kerja. Besarnya estimasi biaya terbesar berturut-turut disebabkan oleh kurangnya komunikasi sebesar Rp. 140.654 .089 atau 54,4 \%, perubahan desain $\mathrm{Rp}$ 111.540.625 atau 43,1 \%, dan kesalahan metode kerja $\mathrm{Rp} 6,454,495$ atau 2,5\%. 


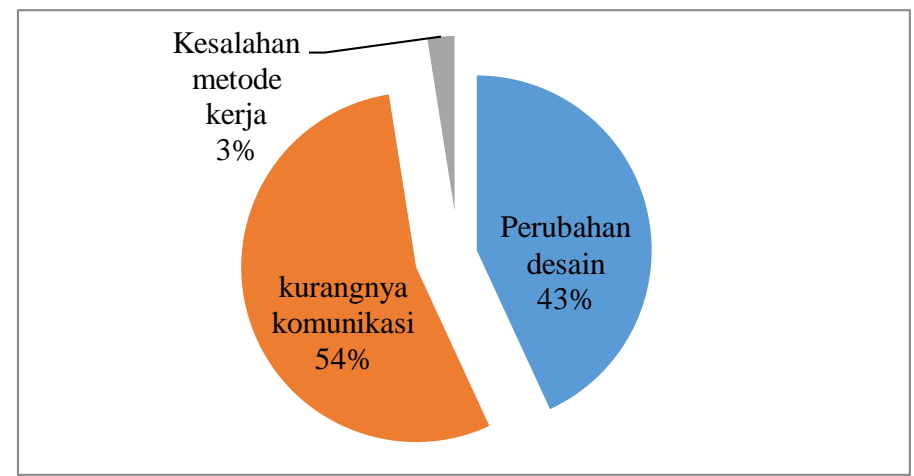

Gambar 1 Persentase estimasi biaya berdasarkan penyebab Rework

\section{Kesimpulan}

Adapun kesimpulan dari penelitian ini adalah:

- Hasil dari wawancara diperoleh 20 item pekerjaan yang mengalami rework, diantaranya adalah pekerjaan plafond, dinding, lantai, pekerjaan artwork, toping sunken lounge. Dari 20 item tersebut, 13 pekerjaan disebabkan oleh kurangnya komunikasi antar kontraktor, 5 pekerjaan disebabkan adanya perubahan desain dari perencana, dan 2 pekerjaan disebabkan oleh kesalahan metode kerja kontraktor.

- Dari hasil analisis perhitungan estimasi biaya langsung diperoleh biaya pekerjaan yang mengalami rework berdasarkan nomor SI adalah SI nomor 34 akibat adanya perubahan desain Rp. 109.329.073,- SI Nomor 205 akibat kurangnya komunikasi Rp. 41.064.625,- SI nomor 260 akibat perubahan desain Rp. 2.211.552,- SI nomor 261 akibat kurangnya komunikasi Rp. 72.544.823,- SI nomor 280 akibat kesalahan metode kerja Rp. 6.454.494,- SI nomor 323 akibat kurangnya komunikasi Rp. 27.044.640,-

- Besarnya estimasi biaya terbesar berturut-turut disebabkan oleh kurangnya komunikasi sebesar Rp. 140.654.089 atau 54,4 \%, perubahan desain Rp 111.540.625 atau $43,1 \%$, dan kesalahan metode kerja Rp. 6.454 .495 atau 2,5\%.

\section{Referensi}

Chundawan, E., \& Alifen, R. S. (2014). Model Sumber dan Penyebab Rework pada Tahapan Proyek Konstruksi. Jurnal Dimensi Utama Teknik Sipil, l(1).

Hamid, D., Alamsyah, T., Mirani, Z., \& Suhanda, O. A. (2019). Analisis Rework Factor pada Pelaksanaan Proyek Gedung di Kota Padang Tahun 2019. Jurnal Ilmiah Rekayasa Sipil, 16(2), 62-75.

Herdianto, A., Tanjungsari, A. D. R., Hidayat, A., \& Hatmoko, J. U. D. (2015). Evaluasi Pengerjaan Ulang (Rework) pada Proyek Konstruksi Gedung di Semarang. Jurnal Karya Teknik Sipil, 4(1), 93-106.

Juliana, H. T., \& Wiguna, I. P. A. (2011). Kajian Pola Rework pada Pelaksanaan Pekerjaan Finshing Perumahan di Surabaya. Prosiding Seminar Nasional Manajemen Teknologi XIII.

Pahlevi, R., \& Sari, S. N. (2020). Analisis Rencana Anggaran Biaya (RAB) Rumah Tipe 86 Di Semarang Jawa Tengah. Equilib, 1(1), 91-102.

Prianto, K. (2014). Analisa Faktor Penyebab Pekerjaan Ulang Pada Proyek Konstruksi di Kota Malang. SISTEM, 10(2).

Rahardjo, K., \& Wiguna, I. P. A. (2011). Analisis Rework pada Konstruksi Gedung di Kabupaten Bondowoso. Prosiding Seminar Nasional Manajemen Teknologi XIV.

Rizal, M., Isya, M., \& Saleh, S. M. (2018). Evaluasi Pekerjaan Ulang (Rework) Pada Proyek Konstruksi Jalan Di Kota Banda Aceh. Jurnal Arsip Rekayasa Sipil Dan Perencanaan, 1(2), $102-112$.

Wongso, A. Y. I., Widjaya, Y. D., \& Alifen, R. S. (2019). Analisis Sisa Material Konstruksi Akibat Rework Pada Pekerjaan Finishing Proyek Rumah Tinggal. Jurnal Dimensi Pratama Teknik Sipil, $8(1), 1-8$. 


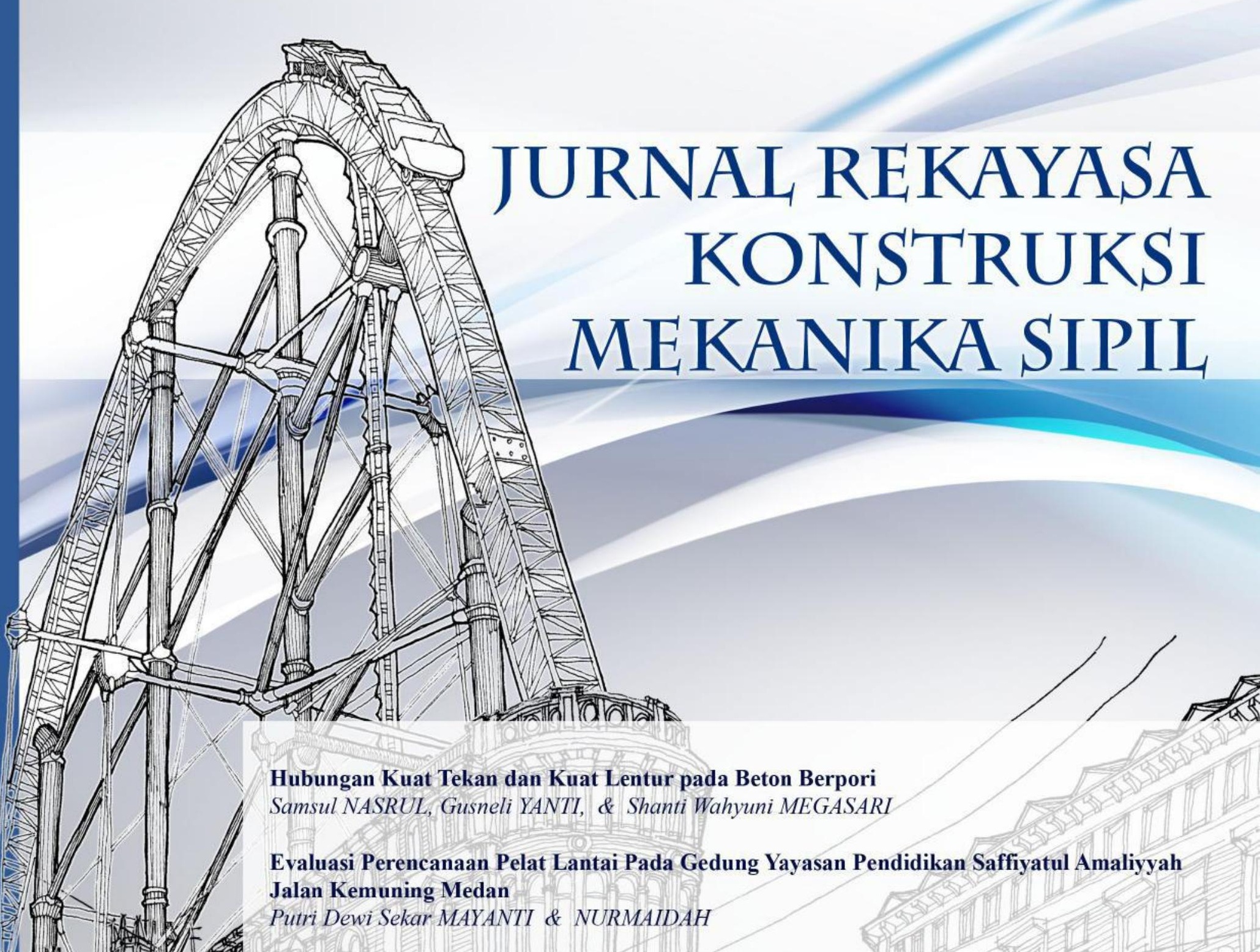

Studi Perencanaan Pondasi Sumuran Pada Pembangunan Gedung Bertingkat Tinggi (Perbandingan Antara Pondasi Tiang Pancang dan Pondasi Sumuran)

Soaloon Prima SIMALANGO, Agus PURBA, \& Kasimir SAWITO

Keinginan Menggunakan Angkot di kota Medan dengan Peningkatan Layanan Informasi Reynaldo SIAHAAN \& TOMmy Iswan LASE

Pengendalian Biaya dan Waktu dengan Metode Earned Value (Studi Kasus: Rancang dan Bangun Sistem Penyediaan Air Minum Kota Dumai 450 LPD Tahap 1A)

Edhi Pandu SUKMONO, ZAINURI, \& Widya APRIANI

Estimasi Besarnya Biaya Proyek Akibat terjadinya Rework pada Pekerjaan Finishing Ni Kadek Sri Ebtha YUNI

Pelaksanaan Manajemen Keselamatan Dan Kesehatan Kerja (SMK3) Pada Proyek Kontruksi, Studi Kasus di Kota Jakarta

Edison Hatoguan MANURUNG, Kasimir SAWITO, \& Isni Rizky YUSHADI

Fakultas Teknik Universitas Katolik Santo Thomas JI. Setia Budi No. 479-F Tanjung Sari, Medan 


\section{Jurnal Rekayasa Konstruksi Mekanika Sipil (JRKMS)}

Jurnal Rekayasa Konstruksi Mekanika Sipil (JRKMS) diterbitkan oleh Fakultas Teknik Universitas Katolik Santo Thomas. JRKMS berisi artikel-artikel ilmiah yang meliputi kajian di bidang Teknik khususnya Teknik Sipil seperti Matematika teknik, Mekanika teknik, Analisis struktur, Konstruksi baja, Konstruksi beton, Konstruksi kayu, Konstruksi gelas, Mekanika tanah, Teknik Pondasi, Hidrologi, Hidrolika, Bangunan air, Manajemen konstruksi, Dinamika Struktur, Earthquake Engineering, Informatika, Ilmu Ukur Tanah, Struktur bangunan sipil, Rekayasa Jalan Raya, serta penelitian-penelitian lain yang terkait dengan bidang-bidang tersebut.

Terbit dalam 2 (dua) kali setahun yaitu pada bulan April dan September

\section{Penasihat :}

Prof. Dr. Drs. Sihol Situngkir, MBA. (Rektor Universitas Katolik Santo Thomas)

\section{Ketua Penyunting (Editor in Chief) :}

Ir. Oloan Sitohang, M.T. (Universitas Katolik Santo Thomas)

Manajer Jurnal (Managing Editor):

Reynaldo, S.T., M.Eng. (Universitas Katolik Santo Thomas)

\section{Anggota Penyunting (Editorial Board):}

Medis Sejahtera Surbakti, S.T, M.T., Ph.D. (Universitas Sumatera Utara)

Dr. Janner Simarmata (Universitas Negri Medan)

Ir. Martius Ginting, M.T. (Universitas Katolik Santo Thomas)

Samsuardi Batubara, S.T., M.T. (Universitas Katolik Santo Thomas)

\section{Mitra Bestari (Peer Reviewer):}

Dr.Eng. Aleksander Purba (Universitas Lampung, Indonesia)

Ir. Binsar Silitonga, M.T. (Universitas Katolik Santo Thomas, Indonesia)

Ir. Charles Sitindaon, M.T. (Universitas Katolik Santo Thomas, Indonesia)

Dr. Erica Elice Uy (De La Salle University, Philippines)

Dr. Harijanto Setiawan (Universitas Atma Jaya Yogyakarta, Indonesia)

Dr.Eng. Jeffry Swingly Frans Sumarauw (Universitas Sam Ratulangi, Indonesia)

Prof. Dr-Ing. Johannes Tarigan (Universitas Sumatera Utara, Indonesia)

Linda Prasetyorini (Universitas Brawijaya, Malang, Indonesia)

Dr.Eng. Mia Wimala (Universitas Katolik Parahyangan, Indonesia)

Dr.Eng. Minson Simatupang (Universitas Halu Oleo, Indonesia)

Dr. Mochamad Raditya Pradana (Keppel Marine and Deepwater Technology, Singapura)

Dr. Senot Sangadji (Universitas Sebelas Maret, Indonesia)

Ir. Simon Dertha, M.T. (Universitas Katolik Santo Thomas, Indonesia)

Dr. Thi Nguyên Cao (Tien Giang University, Viet Nam)

\section{Ilustrator Sampul:}

Yulianto, ST., M.Eng

\section{Penerbit \& Alamat Redaksi:}

Fakultas Teknik Universitas Katolik Santo Thomas

J1. Setiabudi No. 479-F Tanjung Sari, Medan 20132

Telp. (061) 8210161 Fax : (061) 8213269

email : unika.sipil@yahoo.com 


\section{Konten}

REKAYASA STRUKTUR

hal.

Hubungan Kuat Tekan dan Kuat Lentur pada Beton Berpori

Samsul NASRUL, Gusneli YANTI, \& Shanti Wahyuni MEGASARI

Evaluasi Perencanaan Pelat Lantai Pada Gedung Yayasan Pendidikan

Saffiyatul Amaliyyah Jalan Kemuning Medan

Putri Dewi Sekar MAYANTI \& NURMAIDAH

REKAYASA GEOTEKNIK

Studi Perencanaan Pondasi Sumuran Pada Pembangunan Gedung

Bertingkat Tinggi (Perbandingan Antara Pondasi Tiang Pancang dan

Pondasi Sumuran)

Soaloon Prima SIMALANGO, Agus PURBA, \& Kasimir SAWITO

REKAYASA TRANSPORTASI

Keinginan Menggunakan Angkot di kota Medan dengan Peningkatan

Layanan Informasi

Reynaldo SIAHAAN \& Tommy Iswan LASE

MANAJEMEN KONSTRUKSI

Pengendalian Biaya dan Waktu dengan Metode Earned Value (Studi Kasus:

Rancang dan Bangun Sistem Penyediaan Air Minum Kota Dumai 450 LPD

Tahap 1A)

Edhi Pandu SUKMONO, ZAINURI, \& Widya APRIANI

Estimasi Besarnya Biaya Proyek Akibat terjadinya Rework pada Pekerjaan

Finishing

Ni Kadek Sri Ebtha YUNI

Keselamatan dan Kesehatan KerJa

Pelaksanaan Manajemen Keselamatan Dan Kesehatan Kerja (SMK3) Pada

Edison Hatoguan MANURUNG, Kasimir SAWITO, \& Isni Rizky YUSHADI 


\section{Pengantar Redaksi}

Puji dan syukur kami sampaikan kepada Tuhan Yang Maha Esa karena atas rahmatNya kami dapat menyelesaikan penerbitan Jurnal Rekayasa Konstruksi Mekanika Sipil (JRKMS) Volume 4 Nomor 1, di bulan Mei tahun 2021 ini. Jurnal ini fokus pada beragam subbidang dalam Teknik Sipil antara lain Rekayasa Struktur, Rekayasa Geoteknik, Rekayasa Transportasi, Teknik Sumber Daya Air, dan Manajemen Konstruksi. Namun, tidak menutup kesempatan bagi subbidang lainnya yang berkaitan dengan keilmuan Teknik Sipil.

Memasuki tahun ke-2 dalam kondisi pandemi COVID-19, keterbatasan dalam melakukan penelitian tidak menurunkan produktivitas kita dalam meneliti serta mempublikasikannya. Penelitian tetap harus dijalankan dan produktivitas peneliti di Indonesia masih harus terus berkembang. Dalam edisi ini, terdapat 7 artikel yang terdiri atas dua (2) artikel dalam topik Rekayasa Struktur, satu (1) artikel dalam topik Rekayasa geoteknik, satu (1) artikel dalam topik Rekayasa Transportasi, dua (2) artikel dalam topik Manajemen Konstruksi, dan satu (1) artikel dalam topik Keselamatan dan Kesehatan Kerja (K3). Redaksi memiliki kerinduan agar semakin banyak peneliti yang menerbitkan karya berkualitasnya di JRKMS untuk mendukung pengembangan wawasan dalam dunia teknik sipil. Apresiasi kami berikan kepada penulis yang tulisannya diterbitkan pada Volume 04 Nomor 01 Mei 2021 ini karena telah menginvestasikan waktu dalam menuangkan ide dan merespon masukan dari mitra bestari hingga karyanya siap untuk diterbitkan.

Sebagai penutup, yang menjadi harapan tim editorial adalah semoga jurnal ini dapat menjadi media ilmiah yang berguna bagi civitas akademika, dan perkembangan ilmu pengetahuan serta penelitian di bidang ilmu ketekniksipilan di Indonesia. Salam hangat. Salam sehat.

Mei 2021

Tim Editorial 
JURNAL REKAYASA KONSTRUKSI MEKANIKA SIPIL | Volume 4 | Nomor 1 | Mei 2021| Jurnal IImiahTeknik Sipil Fakultas Teknik Universitas Katolik Santo Thomas ejournal.ust.ac.id/index.php/JRKMS

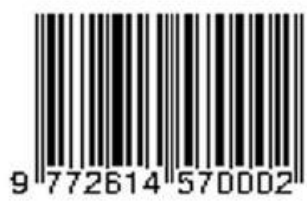

Google RaARUDA ISJDNeo : : neliti Donesearch PBASE 